\title{
PENGARUH KARAKTERISTIK PEMERINTAH DAERAH TERHADAP KEPATUHAN PENGUNGKAPAN INVESTASI PEMERINTAH DAERAH \\ (Studi pada Pemerintah Kabupaten/Kota di Pulau Jawa dan Sumatera)
}

\author{
Sri Suranta* \\ Oktovian Siregar \\ Jurusan Akuntansi Fakultas Ekonomi \\ Universitas Sebelas Maret \\ *srisuranta@yahoo.com
}

\begin{abstract}
This study aims to know the effect of local government's characteristics, which are the local government's administrative age, the size of its investments, the number of SKPDs (working units), the educational background of the head of the local government and intergovernmental revenues, on the compliance of local government investment disclosures and compare the compliance of local government investments disclosures between local governments in Java and Sumatera. The sampling method used is purposive sampling. The study sample consists of 102 district/city governments that report the Local Government Financial Statements for Fiscal Year 2013 and have been audited by the Indonesia's Supreme Audit Board in 2014. This study uses multiple regression analysis and t-test procedure and also does the classical assumptions test including normality, autocorrelation, heteroscedasticity, and multicollinearity test using Statistical Package for the Social Sciences

on the disclosure of local government investments, while the size of its investments, the number of SKPDs (working units), the educational background of the head of the local government and intergovernmental revenues have no significant effect on the disclosure of local government investments.
\end{abstract}

Keywords: local government investment disclosures, local government financial statements, organizational theory, characteristics of an organization.

\section{PENDAHULUAN}

Investasi dimaksudkan untuk memperoleh manfaat ekonomik seperti bunga, dividen dan royalti, atau manfaat sosial sehingga dapat meningkatkan kemampuan pemerintah dalam rangka pelayanan kepada masyarakat. Karena pentingnya manfaat investasi tersebut, laporan keuangan harus menyajikan secara lengkap informasi yang dibutuhkan oleh pengguna. Suhardjanto dan Yulianingtyas (2011) menyatakan bahwa nilai rerata pengungkapan wajib pemerintah daerah di Indonesia tahun 2006 adalah sebesar $51,56 \%$. Hal tersebut menunjukkan bahwa tingkat pengungkapan laporan keuangan rendah.

pemerintah daerah di Indonesia masih

Dari data hasil pemeriksaan Badan Pemeriksa Keuangan (BPK) atas laporan keuangan pemerintah daerah Tahun Anggaran 2014, diketahui bahwa masih terdapat permasalahan dalam penyajian laporan keuangan pemerintah daerah di Indonesia khususnya dalam pengungkapan pos-pos investasi. Misalnya investasi dalam bentuk penyertaan modal pada beberapa BUMD oleh Pemerintah Kabupaten Badung sebesar Rp889,2 miliar yang tidak diyakini kewajaran nilainya karena dokumen pendukung yang tidak memadai.Permasalahan lain yang banyak 
terjadi pada investasi pemerintah daerah di Indonesia adalah pada pengelolaan dan pengungkapan dana bergulir. Permasalahannya antara lain beberapa pemerintah daerah belum memiliki kebijakan akuntansi yang mengatur mengenai penyisihan piutang tak tertagih agar dapat menyajikan nilai investasi dana bergulir berdasarkan nilai bersih yang dapat direalisasikan. Hal tersebut mengakibatkan pemerintah daerah tidak mampu mengawasi dan mengelola penggunaan dana bergulir oleh masyarakat sehingga banyak terjadi dana bergulir yang macet dan bahkan tidak dapat ditelusuri keberadaannya yang dapat merugikan keuangan daerah.

Penelitian terdahulu secara umum meneliti pengungkapan keseluruhan pos-pos neraca, sedangkan penelitian ini secara spesifik meneliti pengungkapan pos investasi serta membandingkan kualitas pengungkapan pemerintah-pemerintah daerah di dua wilayah yang berbeda yaitu di Pulau Jawa dan Sumatera. Selain itu penelitian sebelumnya atas pengungkapan pos investasi hanya mengacu pada Pernyataan Standar Akuntansi Pemerintahan Nomor 06 (PSAP 06) tentang Akuntansi Investasi, sedangkan penelitian ini mencakup juga Buletin Teknis SAP Nomor 7 tentang Akuntansi Dana Bergulir (salah satu komponen investasi) yang baru ditetapkan pada bulan Agustus 2008.

Penelitian ini dilakukan untuk mengetahui sejauh mana pemerintah daerah memenuhi kewajiban pengungkapan investasinya dan apakah pemerintah daerah memiliki kemampuan yang merata dalam memenuhi kewajiban tersebut. Selain itu penelitian ini juga bertujuan untuk mengetahui faktor-faktor yang mempengaruhi kepatuhan pengungkapan investasi dengan mempertimbangkan karakteristik yang dimiliki oleh pemerintah daerah.

Berdasarkan latar belakang dan judul penelitian, maka yang menjadi pokok permasalahan adalah:

1. Apakah karakteristik suatu pemerintah daerah mempengaruhi kualitas pengungkapan investasi dalam laporan keuangan pemerintah daerah?

2. Apakah terdapat perbedaan kepatuhan pengungkapan antara pemerintah daerah di Pulau Jawa dan Sumatera?

Penelitian ini bertujuan untuk mengetahui pengaruh karakteristik daerah terhadap kepatuhan pengungkapan investasi serta membandingkan kepatuhan pengungkapan investasi antara pemerintah daerah di Pulau Jawa dan Sumatera.

\section{LANDASAN TEORI \\ Pengungkapan Investasi Pemerintah Daerah}

Sesuai Peraturan Pemerintah Nomor 71 Tahun 2010 tentang Standar Akuntansi Pemerintahan, Catatan atas Laporan Keuangan harus menyajikan informasi yang diharuskan dan dianjurkan oleh Pernyataan Standar Akuntansi Pemerintahan lainnya serta pengungkapan-pengungkapan lain yang diperlukan untuk penyajian wajar atas laporan keuangan. Khusus untuk pengungkapan yang berkaitan dengan investasi pemerintah daerah, PSAP 06 dan Buletin Teknis 07 mewajibkan pemerintah daerah untuk mengungkapkan hal-hal sebagai berikut: (1) Bentuk investasi, (2) Klasifikasi investasi, (3) Pengakuan investasi, (4) Pengukuran investasi, (5) Metode penilaian investasi, (6) Pengakuan hasil investasi, (7) Pelepasan dan pemindahan investasi, (8) Kebijakan akuntansi untuk penentuan nilai investasi, (9) Jenis-jenis investasi, investasi permanen dan nonpermanen, (10) Perubahan harga pasar baik investasi jangka pendek maupun investasi jangka panjang, (11) Penurunan nilai investasi yang signifikan dan penyebab penurunan tersebut, (12) Investasi yang dinilai dengan nilai wajar dan alasan penerapannya, (13) Perubahan pos investasi, (14) Dasar penilaian dana bergulir, (15) Jumlah dana bergulir yang tidak tertagih dan penyebabnya, (16) Besarnya suku bunga yang dikenakan, (17) Saldo awal dana bergulir, penambahan/pengurangan dana bergulir dan saldo akhir dana bergulir, dan 
(18) Informasi tentang jatuh tempo dana bergulir berdasarkan umur dana bergulir.

Teori Organisasi dan Pengungkapan Investasi Pemerintah Daerah

Teori organisasi adalah suatu studi mengenai bagaimana organisasi berfungsi dan bagaimana organisasi tersebut mempengaruhi dan dipengaruhi oleh lingkungan di mana ia beroperasi (Jones, 2010). Organisasi membentuk kehidupan kita, dan para manajer yang memperoleh informasi tentang organisasi dengan baik dapat membentuk organisasi, dan langkah pertama untuk memahami organisasi adalah dengan melihat ciri-ciri/karakteristik yang menggambarkan sifat-sifat desain organisasional yang spesifik (Daft, 2012). Dengan kata lain, melalui pemahaman ciriciri/karakteristik organisasi, para manajer dapat membentuk dan mengelola organisasi agar dapat berfungsi dengan baik sehingga dapat mencapai tujuan yang telah ditetapkan.

Rogers (2003, dalam Patrick, 2007) menyebutkan bahwa penelitian-penelitian mengenai organizational innovativeness membantu mengidentifikasi pola dan karakteristik organisasi yang inovatif. Penelitian-penelitian tersebut menghasilkan temuan yang konsisten mengenai karakteristik-karakteristik yang berkaitan dengan adopsi dan implementasi dari inovasi (Rogers (2003, dalam Patrick, 2007)). Patrick (2007) mengadaptasi model dari organizational innovativeness Rogers (2003) dalam meneliti faktor-faktor yang mempengaruhi inovasi organisasi dalam mengadopsi GASB 34 dengan mengelompokkan karakteristik organisasi ke dalam budaya organisasi, struktur organisasi, dan lingkungan eksternal.

Karakteristik pemerintah daerah dapat menjelaskan kepatuhan pengungkapan wajib dalam laporan keuangan pemerintah daerah sehingga karakteristik pemerintah daerah merupakan prediktor kepatuhan pengungkapan wajib (Suhardjanto dan Yulianingtyas, 2011). Dalam penelitian tentang kepatuhan pengungkapan wajib, Suhardjanto, etal. (2010) dalam Suhardjanto dan Yulianingtyas (2011) menggunakan dua komponen karakteristik organisasi dari model yang dikembangkan Patrick (2007) yaitu struktur organisasi (municipality size, municipality wealth, functional differentiation, municipality age, educational background of thehead of municipality) dan lingkungan eksternal (municipality debt financing dan intergovernmental revenue).

Dengan mengacu pada penelitian Suhardjanto dan Yulianingtyas (2011), penelitian ini menguji pengaruh karakteristik daerah terhadap kepatuhan pengungkapan investasi dengan menggunakan dua komponen karakteristik organisasi di atas, yaitu struktur organisasi (umur administratif pemerintah daerah, size investasi, jumlah SKPD (diferensiasi fungsional), latar belakang pendidikan kepala daerah) dan lingkungan eksternal (intergovernmental revenue). Dengan memahami ciriciri/karakteristik organisasi (dalam hal ini pemerintah daerah), para manajer (kepala daerah) dapat membentuk dan mengelola organisasinya agar dapat melaksanakan fungsi dengan baik, salah satunya yaitu mengungkapkan laporan keuangannya, sehingga dapat mencapai tujuan yang telah ditetapkan.

\section{Pengaruh Umur Administratif Pemerintah Daerah terhadap Pengungkapan Investasi Pemerintah Daerah}

Umur suatu organisasi dapat diartikan sebagai seberapa lama organisasi tersebut berlangsung sejak didirikannya. Pemerintah daerah dengan umur administratif yang lebih lama akan semakin berpengalaman dan memiliki kemampuan yang lebih baik dalam menyajikan laporan keuangannya secara wajar sesuai dengan SAP (Setyaningrum dan Syafitri, 2012). Dalam penelitian Suhardjanto dan Lesmana (2010), hasilnya menunjukkan bahwa umur administratif pemerintah daerah berpengaruh positif dan signifikan terhadap pengungkapan wajib LKPD. Dari uraian tersebut, disusun hipotesis sebagai berikut:

H1: $\begin{array}{r}\text { Umur } \\ \text { Daerah }\end{array} \begin{array}{r}\text { Administratif } \\ \text { berpengaruh }\end{array} \quad \begin{array}{r}\text { Pemerintah } \\ \text { positif }\end{array}$ 
terhadap Pengungkapan Investasi Pemerintah Daerah.

Pengaruh Size Investasi terhadap Pengungkapan Investasi Pemerintah Daerah

Ukuran organisasi menunjukkan seberapa besar organisasi pemerintah daerah tersebut (Patrick, 2007). Karena investasi pemerintah daerah digunakan dalam rangka pelayanan terhadap masyarakat, maka besarnya investasi akan mendorong pengungkapan dalam laporan keuangan yang lebih akuntabel dan transparan kepada masyarakat. Hasil penelitian yang dilakukan Cooke (1992) dan Patrick (2007) menunjukkan bahwa ukuran organisasi berhubungan positif signifikan dengan tingkat pengungkapan laporan keuangan pemerintah daerah. Dari uraian di atas, maka hipotesis penelitian ini adalah:

H2: Size Size Investasi berpengaruh positif terhadap Pengungkapan Investasi Pemerintah Daerah.

\section{Pengaruh Jumlah SKPD terhadap Pengungkapan Investasi Pemerintah Daerah}

Diferensiasi fungsional menunjukkan sejauh mana sebuah organisasi dibagi menjadi departemen fungsional (Setyaningrum dan Syafitri, 2012). Patrick (2007) menemukan bahwa pemerintah daerah di Pennsylvania dengan tingkat diferensiasi fungsional yang lebih tinggi akan cenderung untuk lebih mengadopsi GovernmentalAccountingStandards Board (GASB) 34 dibandingkan dengan yang tingkat diferensiasi fungsionalnya rendah. Dalam struktur pemerintahan Indonesia, pembagian departemen fungsional direpresentasikan dengan satuan kerja perangkat daerah (SKPD).Semakin banyak jumlah SKPD berarti semakin banyak dan kompleksnya laporan yang harus disusun sehingga tingkat pengungkapan yang dilakukan semakin besar. Dari uraian tersebut, disusun hipotesis sebagai berikut:
H3: Jumlah SKPD berpengaruh positif terhadap Pengungkapan Investasi Pemerintah Daerah.

\section{Pengaruh Intergovernmental Revenue terhadap Pengungkapan Investasi Pemerintah Daerah}

Intergovernmental revenue adalah jenis pendapatan pemerintah daerah yang berasal dari transfer pemerintah pusat kepada pemerintah daerah untuk membiayai kegiatan operasional pemerintah daerah (Patrick, 2007). Intergovernmental revenue yang dikategorikan sebagai lingkungan eksternal memiliki pengaruh positif signifikan terhadap pengungkapan belanja bantuan sosial (Darmastuti dan Setyaningrum, 2012). Semakin besar dana perimbangan yang diperoleh pemerintah daerah mendorong tingkat pengungkapan yang lebih besar kepada pihak pemerintah pusat sebagai bentuk pertanggungjawaban. Dari pernyataan tersebut disusun hipotesis sebagai berikut:

H4: Intergovernmental Revenue berpengaruh positif terhadap Pengungkapan Investasi Pemerintah Daerah.

Pengaruh Latar Belakang Pendidikan Kepala Daerah terhadap Pengungkapan Investasi Pemerintah Daerah

Sebagai pemegang kekuasaan pengelolaan keuangan daerah, kepala daerah dituntut untuk menyusun dan menyajikan laporan keuangan sesuai dengan standar akuntansi pemerintahan (Setyaningrum dan Syafitri, 2012). Kepala daerah dan atau wakil kepala daerah yang memiliki latar belakang ekonomi atau akuntansi akan lebih mudah dalam memahami dan menerapkan standar akuntansi pemerintahan dalam penyajian laporan keuangannya sehingga laporan keuangan menyajikan informasi yang dibutuhkan para pengguna laporan keuangan. Suhardjanto dan Yulianingtyas (2011) menemukan bahwa latar belakang pendidikan bupati merupakan prediktor yang signifikan terhadap kepatuhan pengungkapan 
SAP yang wajib. Dari uraian tersebut, maka disusun hipotesis:

H5: Latar Belakang Pendidikan Kepala Daerah berpengaruh positif terhadap Pengungkapan Investasi Pemerintah Daerah.

\section{Perbandingan}

antara

Pengungkapan Investasi Pemerintah Daerah di Jawa dan Pengungkapan Investasi Pemerintah Daerah di Sumatera

Abdullah (2004) dalam Suhardjanto dan Yulianingtyas (2011) berpendapat bahwa pengendalian sosial dari pemangku kepentingan di luar pemerintahan terhadap pelaksanaan pelayanan publik di luar Pulau Jawa/Bali tidak sebaik di Pulau Jawa/Bali. Adanya pengendalian sosial tersebut akan mendorong pemerintah untuk mengungkapkan elemen pengungkapan wajib sesuai dengan Standar Akuntansi Pemerintahan. Dengan logika tersebut, maka disusun hipotesis:

H6: Terdapat perbedaan antara Pengungkapan Investasi Pemerintah Daerah di Jawa dan Pengungkapan Pemerintah Daerah di Suma

\section{METODOLOGI PENELITIAN Populasi dan Sampel}

Populasi penelitian ini adalah seluruh pemerintah kabupaten/kota di Pulau Jawa dan Sumatera sebanyak 265 entitas. Laporan keuangan pemerintah daerah yang dijadikan sampel adalah laporan keuangan Tahun Anggaran 2013 yang diaudit oleh BPK pada Semester I Tahun 2014. Pemilihan sampel dilakukan dengan cara purposive sampling.

\section{Sumber Data}

Data yang digunakan dalam penelitian ini merupakan data sekunder (secondary data), yaitu data yang dikumpulkan oleh seseorang selain peneliti yang sedang melakukan penelitian tersebut (Sekaran dan Bougie, 2013). Data-data keuangan dan jumlah satuan kerja dalam penelitian ini bersumber dari Laporan
Keuangan Pemerintah Daerah Tahun Anggaran 2013 yang telah diaudit oleh Badan Pemeriksa Keuangan Republik Indonesia. Adapun data umur administratif pemerintah daerah dan latar belakang pendidikan kepala daerah diperoleh dari situs resmi masing-masing pemerintah daerah.

\section{Definisi Operasional dan Pengukuran Variabel}

Operasionalisasi variabel diperlukan untuk memberikan gambaran mengenai variabel-variabel yang digunakan dalam penelitian agar dapat diukur dan dianalisis sesuai dengan tujuan penelitian. Adapun definisi operasional dan pengukuran masingmasing variabel dijelaskan sebagai berikut:

\section{Variabel Dependen}

Penelitian ini menggunakan tingkat Pengungkapan Investasi Pemerintah Daerah dalam komponen Catatan atas Laporan Keuangan (CaLK) berdasarkan PSAP 06 dan Buletin Teknis SAP 07 sebagai variabel dependen. Pengukuran tingkat pengungkapan dilakukan dengan menggunakan sistem scoring dengan mengadopsi penelitian yang dilakukan oleh Setyaningrum dan Syafitri (2012). Sistem scoring yang dimaksud adalah dengan membuat daftar checklist pengungkapan yang diwajibkan PSAP 06 dan Buletin Teknis 07.

Mekanisme yang dilakukan dalam mengukur tingkat pengungkapan adalah: (1) Membuat daftar pengungkapan berdasarkan PSAP 06 dan Buletin Teknis 07, (2) Memberikan nilai untuk setiap pengungkapan dalam LKPD sesuai dengan daftar pengungkapan. Pemberian nilai dibagi menjadi tiga bagian, yaitu "ya", "tidak", dan "not available". Setiap satu item pengungkapan yang sesuai dengan daftar pengungkapan diberi nilai 1 , jika tidak diungkapkan maka diberi nilai 0 , sedangkan "not available item pengungkapan tersebut tidak dapat diaplikasikan, (3) Menjumlahkan nilai-nilai yang didapat untuk setiap LKPD, dan (4) Menghitung tingkat pengungkapan dengan 


\section{JURNAL AKUNTANSI VOL.3 NO. 1 JUNI 2015}

membagi jumlah nilai yang diperoleh dengan nilai maksimum yang seharusnya diperoleh jika melakukan pengungkapan penuh.
Dengan

demikian,

tingkat Pengungkapan Investasi Pemerintah Daerah dapat dihitung dengan rumus:

$$
\text { INVDISC }=\frac{\text { Jumlah } \text { item } \text { yang diungkapkan }}{\text { Total } \text { item } \text { yang harus diungkapkan }}
$$

\section{Variabel Independen}

Variabel independen pada penelitian ini adalah karakteristik Pemerintah Daerah, yaitu Umur Administratif Pemerintah Daerah, Size Investasi, Jumlah SKPD, Intergovernmental Revenue, dan Latar Belakang Pendidikan Kepala Daerah.

\section{Umur Administratif Pemerintah Daerah}

Umur suatu organisasi dapat diartikan seberapa lama organisasi tersebut berlangsung sejak didirikan (Setyaningrum dan Syafitri, 2012). Pendirian suatu pemerintah daerah didasari oleh penetapan undang-undang pembentukan pemerintah daerah. Suhardjanto dan Lesmana (2010) mengukur variabel independen umur pemerintah daerah berdasarkan sejak diterbitkannya peraturan perundangundangan pembentukan daerah yang bersangkutan dan dinyatakan dalam satuan tahun.

AGE $=2013$ - (tahun penetapan undang-undang pembentukan pemerintah daerah)

\section{Size Investasi}

Setyaningrum dan Syafitri (2012) menggunakan total aset Pemerintah Daerah sebagai proksi untuk variabel ukuran Pemerintah Daerah karena aset menunjukkan sumber daya ekonomi yang dikuasai dan atau dimiliki pemerintah sebagai akibat dari peristiwa masa lalu dan dari mana manfaat ekonomi di masa depan diharapkan dapat diperoleh. Karena penelitian ini secara spesifik meneliti pengungkapan investasi maka ukuran/sizeyang digunakan adalah total investasi pemerintah daerah yang diubah ke dalam logaritma natural.

LnTOTINV $=\operatorname{Ln}(\Sigma$ investasi $)$

\section{Jumlah SKPD}

Dalam struktur Pemerintah daerah, pembagian departemen fungsional atau subunit disebut dengan satuan kerja perangkat daerah (SKPD). PP Nomor 24 Tahun 2005 tentang Standar Akuntansi Pemerintahan menjelaskan bahwa SKPD merupakan entitas akuntansi yang diwajibkan menyusun dan menyampaikan laporan keuangan. Jumlah SKPD dianalogikan sebagai segmen bisnis dalam perusahaan sehingga semakin banyak segmen bisnis, semakin banyak hal yang harus diungkapkan. Hilmi dan Martani (2011) menggunakan jumlah SKPD sebagai proksi untuk mengukur diferensiasi fungsional.

SKPD $=\Sigma$ satuan kerja perangkat daerah

Intergovernmental Revenue

Patrick (2007) mendefinisikan intergovernmental revenue sebagai jenis pendapatan Pemerintah Daerah yang berasal dari transfer pemerintah pusat kepada Pemerintah Daerah untuk membiayai operasi 
Pemerintah Daerah. Patrick (2007) dikenal dengan dana perimbangan dari menghitung intergovernmental revenue Pemerintah Pusat. Sumarjo (2010) dengan membagi total intergovernmental menggunakan perbandingan antara total dana revenue dengan total pendapatan. Di perimbangan dengan total pendapatan.

Indonesia, intergovernmental revenue biasa

$$
\text { INTREV }=\frac{\text { Total Dana Perimbangan }}{\text { Total Pendapatan }} \times 100 \%
$$

\section{Latar Belakang Pendidikan Kepala Daerah}

Kepala daerah yang memiliki latar belakang akuntansi akan lebih mudah memahami dan menerapkan standar akuntansi pemerintahan sehingga laporan keuangannya menyajikan informasi yang dibutuhkan para pengguna laporan keuangan. Menurut Suhardjanto dan Yulianingtyas (2011), latar belakang pendidikan Bupati berpengaruh signifikan dalam tingkat pengungkapan wajib LKPD. Variabel ini merupakan variabel dummy, di mana pengukurannya yaitu jika latar belakang kepala daerah dan/atau wakilnya adalah ekonomi, maka bernilai 1. Jika bukan berlatar belakang ekonomi maka bernilai 0 .

Persamaan regresi berganda dalam pengujian hipotesis dirumuskan sebagai berikut:

$$
\begin{aligned}
\text { INVDISC }= & \beta_{0}+\beta_{1} \text { AGE }+\beta_{2} \text { LnTOTINV } \\
& +\beta_{3} \text { SKPD }+\beta_{4} \text { INTREV }+ \\
& \beta_{5} \text { PEND }+\mathrm{e}
\end{aligned}
$$

Keterangan :

INVDISC : Pengungkapan Investasi Pemerintah Daerah

$\begin{array}{ll}\text { AGE } & \text { : Umur Administratif } \\ \text { Pemerintah Daerah } \\ \text { LnTOTINV } & \text { : Size Investasi } \\ \text { SKPD } & \text { : Jumlah SKPD } \\ \text { INTREV } & \text { : Intergovernmental Revenue } \\ \text { PEND } & \text { : Latar Belakang Pendidikan } \\ & \text { Kepala Daerah } \\ \text { e } & \text { :errors }\end{array}$

Koefisien regresi variabel independen yang bernilai positif (+) menunjukkan adanya hubungan berbanding lurus dengan variabel dependen. Sebaliknya, koefisien regresi variabel independen yang bernilai negatif (-) menunjukkan adanya hubungan yang berbanding terbalik dengan variabel dependen.

\section{HASIL DAN PEMBAHASAN Deskripsi Data}

Populasi penelitian ini adalah seluruh pemerintah kabupaten/kota di Pulau Jawa dan Sumatera sebanyak 265 entitas. Pemilihan sampel dilakukan dengan cara purposive sampling. Jumlah dan proses pengambilan sampel dalam penelitian ini

\begin{tabular}{|c|c|}
\hline Kriteria & Jumlah \\
\hline $\begin{array}{l}\text { a. pemerintah provinsi/kabupaten/kota di Pulau Jawa dan } \\
\text { Sumatera. }\end{array}$ & 265 \\
\hline b. Laporan keuangan belum diaudit oleh BPK RI. & $(15)$ \\
\hline $\begin{array}{l}\text { c. Laporan keuangan yang tidak memperoleh opini Wajar Tanpa } \\
\text { Pengecualian atau Wajar Dengan Pengecualian dari BPK. }\end{array}$ & (8) \\
\hline d. Data yang tidak lengkap untuk pengukuran setiap variabel. & $(91)$ \\
\hline Jumlah observasi dalam penelitian & 151 \\
\hline
\end{tabular}
disajikan pada Tabel 1.

Tabel 1

Sampel dan Observasi Penelitian 


\begin{tabular}{lc}
\hline Outlier & $(49)$ \\
\hline Jumlah sampel yang digunakan & 102 \\
\hline
\end{tabular}

Sumber: Data diolah

\section{Statistik deskriptif}

Statistik deskriptif dalam penelitian ini memberikan gambaran umum mengenai karakteristik variabel penelitian meliputi nilai rata-rata (mean), nilai tertinggi/maksimum, nilai terendah/minimum, serta nilai standar deviasi yang menggambarkan penyebaran data. Deskripsi dari data penelitian disajikan dalam Tabel 2.

Tabel 2

Hasil Uji Statistik Deskriptif

\begin{tabular}{lrrrrr}
\hline Variabel & $N$ & Minimum & Maximum & Mean & \multicolumn{1}{c}{ Std. Deviation } \\
\hline AGE & 102 & 5,000 & 71,000 & 49,059 & 21,360 \\
LnTOTINV & 102 & 20,801 & 28,234 & 24,737 & 1,134 \\
SKPD & 102 & 29,000 & 170,000 & 54,098 & 19,498 \\
INTREV & 102 & 0,467 & 0,962 & 0,859 & 0,093 \\
PEND & 102 & - & 1,000 & 0,333 & 0,474 \\
INVDISC & 102 & 0,500 & 0,810 & 0,653 & 0,081 \\
Valid N (listwise) & 102 & & & & \\
\hline
\end{tabular}

Sumber: Data diolah

\section{Uji Asumsi Klasik}

Uji asumsi klasik penelitian ini meliputi normalitas, autokorelasi, heteroskedastisitas, dan multikolinieritas.Uji normalitas menggunakan uji KolmogorovSmirnov dengan hasil uji menunjukkan nilai signifikansi sebesar 0,320 (lebih besar dari $\alpha$ $=5 \%)$. Uji autokorelasi menggunakan Run Test dengan signifikansi sebesar 0,232 (lebih

menggunakan Uji Glejser dengan hasil menunjukkan bahwa nilai probabilitas lebih besar dari 5\%. Hasil uji multikolinieritas menunjukkan bahwa nilai tolerance lebih besar dari 0,1 dan VIF kurang dari 10 pada setiap variabel. Dengan demikian, dapat ditarik kesimpulan bahwa keempat asumsi klasik telah terpenuhi.

\section{Hasil Pengujian Hipotesis}

Pengujian hipotesis dalam penelitian ini menggunakan analisis regresi berganda (uji statistik $\mathrm{F}$, uji statistik $\mathrm{t}$, dankoefisien determinasi) dan uji beda t-test.

\section{Uji Signifikansi Simultan (Uji Statistik F)}

Uji statistik $F$ pada dasarnya menunjukkan apakah semua variabel independen atau bebas yang dimasukkan dalam model mempunyai pengaruh secara bersama-sama terhadap variabel dependen/terikat (Ghozali, 2013). BerdasarkanTabel 3, nilai $F$ hasil perhitungan adalah 6,692 sedangkan nilai $\mathrm{F}$ tabel adalah 2,309. Karena nilai $\mathrm{F}$ hitung lebih besar daripada nilai $\mathrm{F}$ tabel maka variabel independen secara statistik mempengaruhi variabel dependen secara bersama-sama.

Uji statistik $\mathrm{F}$ juga digunakan untuk menentukan goodness of fit atau kelayakan model regresi yang digunakan dalam melakukan pengujian hipotesis dalam penelitian. Dari Tabel 3 diketahui bahwa probabilityvalue ( $p$-value) adalah sebesar 0,000 . Karena $p$-value dalam hasil pengujian lebih kecil dari 5\%, maka model layak (fit) untuk digunakan sebagai model regresi dalam penelitian. 
Tabel 3

Hasil Uji Signifikansi Simultan (Uji Statistik F)

\begin{tabular}{|c|c|c|c|c|c|}
\hline Model & $\begin{array}{c}\text { Sum of } \\
\text { Squares }\end{array}$ & $D f$ & $\begin{array}{c}\text { Mean } \\
\text { Square }\end{array}$ & $F$ & Sig. \\
\hline \multirow{3}{*}{$\begin{array}{ll}1 & \text { Regression } \\
& \text { Residual } \\
& \text { Total }\end{array}$} & 0,173 & 5 & 0,035 & \multirow[t]{3}{*}{6,692} & \multirow[t]{3}{*}{$0,000^{b}$} \\
\hline & 0,497 & 96 & 0,005 & & \\
\hline & 0,671 & 101 & & & \\
\hline \multicolumn{6}{|c|}{ a. DependentVariable: INVDISC } \\
\hline \multicolumn{6}{|c|}{ b. Predictors: (Constant), PEND, LnTOTINV, SKPD, INTREV, AGE } \\
\hline
\end{tabular}

Uji Signifikansi Parameter Individual (Uji Statistik t)

Uji statistik t pada dasarnya menunjukkan seberapa jauh pengaruh satu variabel penjelas/independen secara individual dalam menerangkan variasi variabel dependen (Ghozali, 2013). Tabel 4 menunjukkan bahwa variabel umur administratif pemerintah daerah (AGE) memiliki p-value lebih kecil dari 0,05 yaitu sebesar 0,000. Dengan demikian, hipotesis yang menyatakan bahwa umur administratif pemerintah daerah berpengaruh positif terhadap pengungkapan investasi pemerintah daerah diterima. Sementara itu, variabel size investasi (LnTOTINV), jumlah SKPD (SKPD), intergovernmentalrevenue (INTREV), dan latar belakang pendidikan kepala daerah (PEND) memiliki p-value lebih besar dari 0,05 sehingga hipotesis yang menyatakan bahwa variabel-variabel tersebut berpengaruh positif terhadap pengungkapan investasi pemerintah daerah ditolak.

Tabel 4

Hasil Uji Signifikansi Parameter Individual (Uji Statistik t)

\begin{tabular}{|c|c|c|c|c|c|c|}
\hline & \multirow[t]{2}{*}{ Model } & \multicolumn{2}{|c|}{$\begin{array}{c}\text { UnstandardizedCo } \\
\text { efficients }\end{array}$} & \multirow{2}{*}{$\begin{array}{c}\begin{array}{c}\text { Standardized } \\
\text { Coefficients }\end{array} \\
\text { Beta }\end{array}$} & \multirow[t]{2}{*}{$t$} & \multirow[t]{2}{*}{ Sig. } \\
\hline & & $B$ & Std. Error & & & \\
\hline \multirow[t]{6}{*}{1} & (Constant) & 0,515 & 0,223 & & 2,314 & 0,023 \\
\hline & $A G E$ & 0,002 & 0,000 & 0,433 & 4,384 & 0,000 \\
\hline & LnTOTINV & 0,005 & 0,008 & 0,070 & 0,667 & 0,507 \\
\hline & $S K P D$ & 0,000 & 0,000 & 0,040 & 0,425 & 0,672 \\
\hline & INTREV & $-0,082$ & 0,086 & $-0,094$ & $-0,951$ & 0,344 \\
\hline & PEND & $-0,017$ & 0,015 & $-0,101$ & $-1,127$ & 0,263 \\
\hline
\end{tabular}

a. DependentVariable: INVDISC

\section{Koefisien Determinasi}

Koefisien determinasi $\left(\mathrm{R}^{2}\right)$ pada intinya mengukur seberapa jauh kemampuan model dalam menerangkan variasi variabel independen (Ghozali, 2013).Tabel 5 menunjukkan bahwa nilai Adjusted $\mathrm{R}^{2}$ sebesar 0,220 atau 22,0\%. Hasil tersebut mengindikasikan bahwa variabel-variabel independen dalam penelitian ini mampu menjelaskan variabilitas variabel dependen pengungkapan investasi pemerintah daerah sebesar $22,0 \%$, sedangkan sisanya sebesar $78,0 \%$ dijelaskan oleh variabel lain di luar model penelitian ini. 


\section{Tabel 5}

Hasil Uji Koefisien Determinasi

\begin{tabular}{lcccr}
\hline Model & $R$ & $R$ Square & Adjusted $R$ Square & $\begin{array}{c}\text { Std. Error of } \\
\text { theEstimate }\end{array}$ \\
\hline 1 & $0,508^{\mathrm{a}}$ & 0,258 & 0,220 & 0,07198 \\
\hline a. Predictors: (Constant), PEND, LnTOTINV, SKPD, INTREV, AGE & \\
b. DependentVariable: INVDISC & & \\
\hline
\end{tabular}

\section{Uji Beda T-test}

Dari Tabel 6 terlihat bahwa rata-rata pengungkapan investasi pemerintah daerah di Jawa adalah 0,6844 sedangkan pengungkapan investasi pemerintah daerah di Sumatera adalah 0,6095. Secara absolut jelas bahwa rata-rata pengungkapan investasi pemerintah daerah berbeda antara di Pulau Jawa dan Sumatera. Dari Tabel 7 diketahui bahwa F hitung Levene's Test sebesar 0,021 dengan probabilitas 0,885 . Karena probabilitas $>0,05$ maka disimpulkan bahwa
$\mathrm{H}_{0}$ tidak dapat ditolak atau memiliki variance yang sama. Dengan demikian, analisis uji beda t-test harus menggunakan asumsi equal variances assumed. Dari tabel tersebut, terlihat bahwa nilai t pada equal variances assumed adalah 5,123 dengan probabilitas signifikansi 0,000 (two-tailed). Jadi dapat disimpulkan bahwa rata-rata pengungkapan investasi pemerintah daerah berbeda secara signifikan antara pemerintah daerah di Jawa dan di Sumatera.

Tabel 6

Group Statistics

\begin{tabular}{cccccc}
\hline \multicolumn{2}{c}{ LOKASI } & $N$ & Mean & Std. Deviation & Std. ErrorMean \\
\hline INVDISC & $\mathrm{J}$ & 59 & 0,6844 & 0,07288 & 0,00949 \\
& $\mathrm{~S}$ & 43 & 0,6095 & 0,07290 & 0,01112 \\
\hline
\end{tabular}

Tabel 7

Independent Samples Test

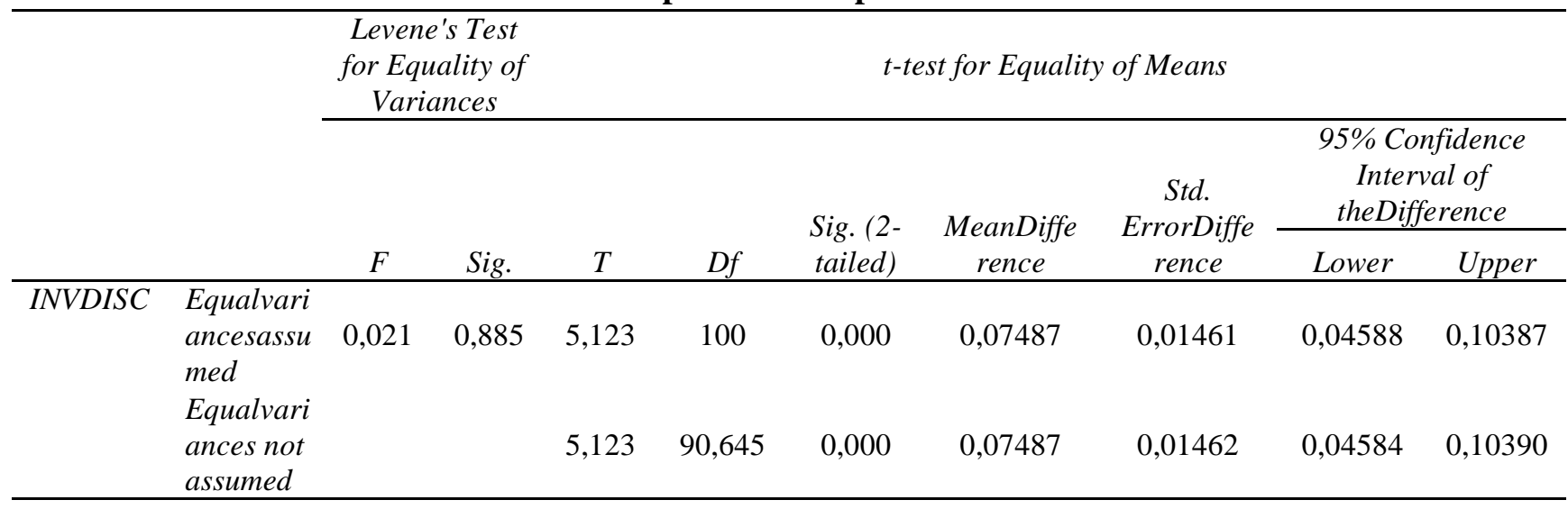


PEMBAHASAN

\section{Pengaruh Umur \\ Pemerintah Daerah \\ Pengungkapan Investasi Pemerintah \\ Daerah}

Berdasarkan hasil uji signifikansi parameter individual padaTabel 4, diketahui bahwa nilai probabilitas signifikansi variabel umur administratif pemerintah daerah sebesar 0,000dengan koefisien regresi 0,515 (positif). Hal tersebut berarti bahwa umur administratif pemerintah daerah berpengaruh positif signifikan terhadap pengungkapan investasi pemerintah daerah pada $\alpha=5 \%$. Dengan demikian, hipotesis pertama $\left(\mathrm{H}_{1}\right)$ yang menyatakan bahwa umur administratif pemerintah daerah berpengaruh positif terhadap pengungkapan investasi pemerintah daerah dapat diterima. Hasil ini sejalan dengan penelitian Suhardjanto dan Lesmana (2010) serta Setyaningrum dan Syafitri (2012).

Setyaningrum dan Syafitri (2012) menyatakan bahwa adanya pengaruh positif yang signifikan antara umur administratif Pemerintah Daerah dan tingkat pengungkapan LKPD disebabkan karena Pemda yang sudah lama berdiri memiliki lebih banyak informasi yang dapat diungkapkan dibandingkan dengan Pemerintah Daerah yang baru berdiri. Dengan kata lain, dengan sistem administrasi dan tata kelola yang sudah mapan yang didukung dengan pengalaman para birokratnya, pemerintah daerah dengan umur administratif yang lebih tua memiliki kemampuan yang lebih baik dalam melaksanakan tugas-tugasnya, khususnya yang terkait dengan kewajiban pengungkapan investasi pemerintah daerah.

\section{Pengaruh Size Investasi terhadap Pengungkapan Investasi Pemerintah Daerah}

Walaupun koefisien regresi size investasi bernilai positif yaitu 0,005 , nilai probabilitas signifikansinya sebesar 0,507 $=5 \%$, yang berarti bahwa size investasi tidak berpengaruh signifikan terhadap pengungkapan investasi pemerintah daerah. Hal ini berarti bahwa hipotesis kedua $\left(\mathrm{H}_{2}\right)$ yang menyatakan bahwa size investasi berpengaruh positif terhadap pengungkapan investasi pemerintah daerah ditolak. Hasil penelitian ini sejalan dengan penelitian Darmastuti dan Setyaningrum (2012), Hilmi dan Martani (2011), Miranti (2009) dan Suhardjanto dan Yulianingtyas (2011).

Pemerintah Daerah dengan size yang besar memiliki masalah birokrasi yang lebih besar sehingga mengakibatkan proses penerapan SAP lebih rumit jika dibandingkan dengan pemerintah daerah yang kecil (Suhardjanto dan Yulianingtyas, 2011). Khusus untuk investasi pemerintah daerah dalam bentuk investasi nonpermanen dana bergulir yang dipinjamkan untuk dikelola oleh masyarakat, semakin besar size investasinya jelas semakin sulit penatausahaannya karena masyarakat penerima dana tersebut tersebar di seluruh wilayah pemerintah daerah tersebut. Selain itu, dana bergulir umumnya diberikan tidak dalam bentuk uang tunai melainkan dalam bentuk hewan ternak atau peralatan tani yang tentunya semakin sulit untuk diawasi penyalurannya, pelunasan pinjamannya maupun pencatatannya.

\section{Pengaruh Jumlah SKPD terhadap Pengungkapan Investasi Pemerintah Daerah}

Dari hasil uji signifikansi parameter individual, diketahui bahwa nilai probabilitas signifikansi variabel jumlah SKPD sebesar 0,672. Karena nilai probabilitas signifikansinya lebih besar dari 5\%, berarti jumlah SKPD tidak berpengaruh signifikan terhadap pengungkapan investasi pemerintah daerah. Hal ini berarti bahwa hipotesis ketiga yang menyatakan bahwa jumlah SKPD berpengaruh positif terhadap pengungkapan investasi pemerintah daerah ditolak. Hasil penelitian ini sejalan dengan Setyaningrum dan Syafitri (2012), Darmastuti dan Setyaningrum (2012), Hilmi dan Martani (2011), dan Suhardjanto dan Yulianingtyas (2011).

Setyaningrum dan Syafitri (2012) berpendapat bahwa pemerintah daerah 
dengan jumlah SKPD yang besar memiliki birokrasi yang lebih kompleks, sehingga tingkat pengawasan terhadap transaksitransaksi yang terjadi di pemerintah daerah dapat dikatakan rendah. Hal ini mengakibatkan besarnya potensi pencatatan yang tidak akurat. Terlebih lagi dalam investasi pemerintah daerah khususnya dana bergulir, pengelolaannya membutuhkan koordinasi lintas SKPD karena setiap SKPD memiliki tanggung jawab terpisah antara yang mencairkan dana, menyalurkan, dan mengawasi pelaksanaannya di lapangan.

\section{Pengaruh Intergovernmental Revenue terhadap Pengungkapan Investasi Pemerintah Daerah}

Hasil uji signifikansi parameter individual menunjukkan bahwa nilai probabilitas signifikansi variabel intergovernmental revenue sebesar 0,344. Nilai probabilitas signifikansi tersebut lebih besar dari $\alpha=5 \%$. Dengan demikian, intergovernmental revenue tidak berpengaruh signifikan terhadap pengungkapan investasi pemerintah daerah. Hal ini berarti bahwa hipotesis keempat yang menyatakan bahwa intergovernmental revenue berpengaruh positif terhadap pengungkapan investasi pemerintah daerah ditolak. Hal ini sejalan dengan hasil penelitian Martani dan Lestari (2010) dan Hilmi dan Martani (2011).

Hilmi dan Martani (2011) berpendapat bahwa kemungkinan dalam era desentralisasi hubungan pemerintah pusat dan daerah tidak terlalu erat sehingga tidak ada monitoring khusus pelaporan keuangan Pemda oleh Pemerintah Pusat. Selain itu, dana yang ditransfer oleh pemerintah pusat kepada pemerintah daerah tidaklah berdasarkan kepatuhan pelaporan melainkan karena transfer yang bersifat otomatis (Martani dan Lestari, 2010). Dengan kata lain, intergovernmentalrevenuedipandang oleh pemerintah daerah sebagai hak yang harus dipenuhi oleh pemerintah pusat karena diamanatkan oleh Undang-Undang Nomor 33 Tahun 2004 tentang Perimbangan Keuangan antara Pemerintah Pusat dan Pemerintahan Daerah.
Pengaruh Latar Belakang Pendidikan Kepala Daerah terhadap Pengungkapan Investasi Pemerintah Daerah

Dari hasil uji signifikansi parameter individual, diketahui bahwa nilai probabilitas signifikansi variabel latar belakang pendidikan kepala daerah sebesar 0,263. Karena nilai probabilitas signifikansinya $=5 \%$, dapat disimpulkan

bahwa latar belakang pendidikan kepala daerah tidak berpengaruh signifikan terhadap pengungkapan investasi pemerintah daerah. Hal ini berarti bahwa hipotesis kelima yang menyatakan bahwa latar belakang pendidikan kepala daerah berpengaruh positif terhadap pengungkapan investasi pemerintah daerah ditolak. Hal ini sejalan dengan hasil penelitian Setyaningrum dan Syafitri (2012) dan Darmastuti dan Setyaningrum (2012).

Peraturan Pemerintah Republik Indonesia Nomor 58 Tahun 2005 tentang Pengelolaan Keuangan Daerah menyebutkan bahwa kepala daerah selaku kepala pemerintah daerah adalah pemegang kekuasaan pengelolaan keuangan daerah dan mewakili pemerintah daerah dalam kepemilikan kekayaan daerah yang dipisahkan. Selaku pemegang kekuasaan pengelolaan keuangan daerah, kepala daerah mempunyai kewenangan seperti menetapkan kebijakan-kebijakan tentang pelaksanaan APBD dan menetapkan pejabat-pejabat untuk melaksanakan APBD tersebut. Karena kepala daerah berada pada tingkat penentu kebijakan APBD sementara pelaksanaannya didelegasikan kepada pejabat lain, latar belakang pendidikan kepala daerah baik ekonomi maupun nonekonomi tidak berpengaruh langsung terhadap pelaksanaan APBD, pelaporan dan pengungkapan keuangan daerah.

\section{Perbandingan antara Pengungkapan Investasi Pemerintah Daerah di Jawa dan Pengungkapan Investasi Pemerintah Daerah di Sumatera}

Dari hasil uji beda T-test padaTabel 6 diketahui bahwa rata-rata pengungkapan investasi pemerintah daerah di Jawa adalah 
$68,44 \%$ sedangkan pengungkapan investasi pemerintah daerah di Sumatera adalah $60,95 \%$. Secara absolut, dapat disimpulkan bahwa rata-rata pengungkapan investasi pemerintah daerah berbeda antara di Pulau Jawa dan Sumatera. Dari Tabel 7 diketahui bahwa nilai t pada equalvariances assumed adalah 5,123 dengan probabilitas signifikansi 0,000 (two-tailed) sehingga disimpulkan bahwa rata-rata pengungkapan investasi pemerintah daerah berbeda secara signifikan antara pemerintah daerah di Jawa dan di Sumatera. Dengan demikian hipotesis keenam yang menyatakan bahwa terdapat perbedaan antara pengungkapan investasi pemerintah daerah di Jawa dan pengungkapan investasi pemerintah daerah di Sumatera diterima. Hasil penelitian ini berbeda dengan hasil penelitian Suhardjanto dan Yulianingtyas (2011) yang tidak menemukan perbedaan antara tingkat pengungkapan wajib dalam LKPD pemerintah daerah di Pulau Jawa/Bali dan di luar Pulau Jawa/Bali.

Tidak dapat dipungkiri bahwa terdapat kesenjangan antara Pulau Jawa dengan pulau lainnya termasuk Sumatera dalam hal pembangunan infrastruktur, sumber daya manusia dan teknologi informasi. Kesenjangan dalam hal tersebut dapat berkontribusi pada timbulnya perbedaan kemampuan antara pemerintah daerah di Pulau Jawa dan Sumatera dalam melaksanakan tanggung jawab pengelolaan keuangan daerahnya. Kemampuan tersebut termasuk juga dalam hal kemampuan memenuhi kewajiban mengungkapkan pospos dalam laporan keuangan khususnya yang berkaitan dengan pengungkapan investasi pemerintah daerah.

\section{SIMPULAN， KETERBATASAN， DAN SARAN \\ Simpulan}

Penelitian ini bertujuan untuk mengetahui pengaruh karakteristik daerah terhadap kepatuhan pengungkapan investasi serta membandingkan kepatuhan pengungkapan investasi antara pemerintah daerah di Pulau Jawa dan Sumatera. Hasil penelitian ini menyimpulkan bahwa:

a. Umur administratif pemerintah daerah secara signifikan mempengaruhi pengungkapan investasi pemerintah daerah. Dengan sistem administrasi dan tata kelola yang sudah mapan yang didukung dengan pengalaman para birokratnya, pemerintah daerah dengan umur administratif yang lebih tua memiliki kemampuan yang lebih baik dalam melaksanakan tugas-tugasnya, khususnya yang terkait dengan kewajiban pengungkapan investasi pemerintah daerah.

b. Size investasi, Jumlah SKPD, Latar belakang pendidikan kepala daerah dan Intergovernmental Revenue tidak berpengaruh signifikan terhadap pengungkapan investasi pemerintah daerah. Hal ini sejalan dengan penelitian Suhardjanto dan Yulianingtyas (2011) yang berpendapat bahwa Pemerintah Daerah dengan size yang besar memiliki masalah birokrasi yang lebih besar sehingga mengakibatkan proses penerapan SAP lebih rumit jika dibandingkan dengan pemerintah daerah yang kecil.

c. Terdapat perbedaan antara pengungkapan investasi pemerintah daerah di Jawa dan pengungkapan investasi pemerintah daerah di Sumatera. Kesenjangan antara Pulau Jawa dengan pulau lainnya termasuk Sumatera dalam hal pembangunan infrastruktur, sumber daya manusia dan teknologi informasi dapat berkontribusi pada timbulnya perbedaan kemampuan antara pemerintah daerah di Pulau Jawa dan Sumatera dalam melaksanakan tanggung jawab pengelolaan keuangan daerahnya.

\section{Keterbatasan dan Saran}

Keterbatasan penelitian ini adalah adanya keterbatasan data yang diperoleh dan dapat diolah untuk mengukur variabelvariabel dan menguji hipotesis-hipotesis penelitian. Dari 265 pemerintah kabupaten/kota yang ada di Pulau Jawa dan 
Sumatera, hanya 102 sampel yang dapat digunakan dalam penelitian ini. Selain itu penelitian ini hanya menguji pengaruh lima karakteristik pemerintah daerah terhadap pengungkapan investasi pemerintah daerah, sementara masih ada karakteristikkarakteristik lain yang dapat dipilih untuk diuji misalnya tingkat kesejahteraan (wealth), status daerah, dan tingkat pembiayaaan utang (debtfinancing).

\section{DAFTAR PUSTAKA}

Badan Pengembangan dan Pembinaan Bahasa. 2015. Kamus Besar Bahasa Indonesia.

http://kbbi.web.id/karakteristik (diakses tanggal 6 Juli 2015).

Cooke, T. E. 1992. The Impact of Size, Stock Market Listingand Industrial Type

DisclosureintheAnnualReports of JapaneseListedCorporations.

Accountingand Business Research. Vol. 22, No. 87, pp. 229-237.

Daft, R. L. 2012. Organization TheoryandDesign. EleventhEdition. South-Western, CengangeLearning.

Darmastuti, D. dan D. Setyaningrum. 2012. Faktor-faktor yang Mempengaruhi Pengungkapan Belanja Bantuan Sosial pada Laporan Keuangan Pemerintah Daerah Pada Tahun 2009. Proceedings Simposium Nasional Akuntansi 15, Banjarmasin, September 2012.

Jones, G. R. 2010. OrganizationalTheory, Design, andChange. SixthEdition. Prentice Hall.

Ghozali, I. 2013. Analisis Multivariate dengan Program SPSS. Semarang: BP UNDIP.
Berdasarkan keterbatasan penelitian ini, beberapa saran yang dapat diberikan untuk penelitian selanjutnya adalah menguji karakteristik-karakteristik pemerintah daerah yang lain yang belum tercakup dalam penelitian ini dan mencari alternatif sumber data selain dari laporan keuangan dan situs resmi pemerintah daerah.

Hilmi, A. Z. dan D. Martani. 2012. Analisis Faktor-Faktor yang Mempengaruhi Tingkat Pengungkapan Laporan Keuangan Pemerintah Provinsi. Proceedings Simposium Nasional Akuntansi 15, Banjarmasin, September 2012.

\section{Ikhtisar Hasil Pemeriksaan Semester I} Tahun 2014. 2014. Jakarta: Badan Pemeriksa Keuangan Republik Indonesia.

Komite Standar Akuntansi Pemerintahan (KSAP). 2008. Akuntansi Dana Bergulir. Buletin Teknis Standar Akuntansi Pemerintahan Nomor 07. Jakarta: KSAP.

Komite Standar Akuntansi Pemerintahan (KSAP). 2010. Standar Akuntansi Pemerintahan. Peraturan Pemerintah Nomor 71 Tahun 2010. Jakarta: KSAP.

Martani, D. dan A. Lestari. 2010. LocalGovernment Financial StatementDisclosurein Indonesia. In Proceedings of the 2010 AnnualMeetingand Conference Asian AcademicAccounting Association (AAAA). Bangkok, Thailand: Thammasat Business School.

Miranti, L. 2009. Praktik Penerapan IndonesianEnvironmentalReportingI ndex dan Kaitannya dengan Karakteristik Perusahaan. Skripsi S1 Fakultas Ekonomi Universitas Sebelas Maret Surakarta. 
Patrick, P. A. 2007. The Determinants of OrganizationalInnovativeness: The Adoption of GASB 34 inPennsylvaniaLocalGovernment. UnpublishedPh.DDissertation. Pennsylvania: The Pennsylvania State University.

Peraturan Pemerintah Republik Indonesia Nomor 58 Tahun 2005 tentang Pengelolaan Keuangan Daerah.

Ryan, C., T. Stanley, dan M. Nelson. 2002. AccountabilityDisclosuresby Queensland LocalGovernmentCouncils: $1997-$ 1999. Financial Accountability\& Management 18 (3): pp. 261-289.

Sekaran, U. dan R. Bougie. 2013. Research Methods for Business. SixthEdition. John Wileyand Sons Inc.

Setyaningrum, D. dan F. Syafitri. 2012. Analisis Pengaruh Karakteristik Pemerintah Daerah terhadap Tingkat Pengungkapan Laporan Keuangan. Jurnal Akuntansi dan Keuangan Indonesia. Vol. 9, No. 2, hal 154170.

Suhardjanto, D. dan S. I. Lesmana. 2010. Pengaruh Karakteristik Pemerintah Daerah Terhadap Tingkat Pengungkapan Wajib di Indonesia. Prestasi Vol. 6: ISSN 1411-1497.

, dan R. R. Yulianingtyas. 2011. Pengaruh Karakteristik Pemerintah Daerah terhadap Kepatuhan Pengungkapan Wajib dalam Laporan Keuangan Pemerintah Daerah (Studi Empiris pada Kabupaten/Kota di Indonesia). Jurnal Akuntansi dan Auditing Vol. 8: ISSN 1412-6699.

Sumarjo, H. 2010. Pengaruh Karakteristik Pemda terhadap Kinerja Keuangan
Pemda. Skripsi S1 Fakultas Ekonomi Universitas Sebelas Maret Surakarta.

Undang-Undang Nomor 33 Tahun 2004 tentang Perimbangan Keuangan antara Pemerintah Pusat dan Pemerintahan Daerah. 